Abstract-The Argentine sea bass (Acanthistius patachonicus) is one of the most conspicuous and abundant species in the rocky-reef fish assemblage of Northern Patagonia, which sustains important recreational and commercial activities, such as scuba diving, hook-and-line fishing, and spear fishing. We describe the morphological features of eggs, larvae, and posttransition juveniles of A. patachonicus and summarize abundance and distribution data for larvae collected on the Argentine shelf (between $\sim 40^{\circ} \mathrm{S}$ and $44^{\circ} \mathrm{S}$ ). Eggs and yolk-sac larvae came from an in vitro fertilization experiment. Larger larvae were distinguished by relevant morphological features, including the development of the opercular complex and head spination, meristics, and pigmentation pattern. The early stages of $A$. patachonicus are similar to those of the koester (A. sebastoides) and of the western wirrah (A. serratus), the other 2 species of Acanthistius whose larval development has been described. The body and head in A. patachonicus were moderate in size, but its preanal length was long. The particular head spination pattern of larvae of A. patachonicus, namely a few conspicuous smooth spines (mainly on the preopercle and opercle), and 2 posttemporal spines, was useful for differentiating this species from others and, therefore, made it possible to describe the whole developmental series and to link the early stage morphological features to those of adults.

Manuscript submitted 5 November 2014. Manuscript accepted 18 August 2015. Fish. Bull. 113:456-467 (2015).

Online publication date: 10 September 2015. doi: 10.7755/FB.113.8

The views and opinions expressed or implied in this article are those of the author (or authors) and do not necessarily reflect the position of the National Marine Fisheries Service, NOAA.

\title{
Early life history of the Argentine sea bass (Acanthistius patachonicus) (Pisces: Serranidae)
}

\author{
Lujan Villanueva Gomila (contact author) ${ }^{1}$ \\ Martín. D. Ehrlich ${ }^{2,3}$ \\ Leonardo A. Venerus 1 \\ Email address for contact author: gomila@cenpat-conicet.gob.ar \\ 1 Centro Nacional Patagónico (CENPAT) \\ Consejo Nacional de Investigaciones Científicas y Técnicas (CONICET) \\ Boulevard Brown 2915 \\ Puerto Madryn \\ Chubut, U9120ACD Argentina \\ 2 Instituto Nacional de Investigación y Desarrollo Pesquero (INIDEP) \\ P.O. Box 175 \\ Mar del Plata \\ Buenos Aires, B7602HSA Argentina \\ 3 Instituto de Ecología, Genética y Evolución de Buenos Aires (IEGEBA) \\ CONICET \\ Facultad de Ciencias Exactas y Naturales \\ Universidad de Buenos Aires (UBA) \\ Intendente Güiraldes 2160 \\ Ciudad Universitaria \\ Ciudad Autónoma de Buenos Aires, C1428EGA Argentina
}

The genus Acanthistius, included in the speciose family Serranidae (Nelson, 2006; but see Smith and Craig, 2007), is represented by 2 species in the Southwest Atlantic Ocean: Acanthistius brasilianus, which ranges from $15^{\circ} \mathrm{S}$ (Brazil) to $36^{\circ} \mathrm{S}$ (Uruguay) (Irigoyen et al., 2008) and Acanthistius patachonicus, which ranges from $23^{\circ} \mathrm{S}$ in Brazil to $48^{\circ} \mathrm{S}$ on the Argentine shelf (Irigoyen et al., 2008), at depths of $0-100 \mathrm{~m}$ (Cousseau and Perrotta, 2000). Until recently, $A$. patachonicus was misclassified as $A$. brasilianus, giving rise to a nomenclatural confusion in the ichthyological literature from Argentina. Irigoyen et al. (2008) clarified the taxonomic status of the species of Acanthistius in the Southwest Atlantic Ocean and developed a new diagnostic key to discriminate between these taxa.

Acanthistius patachonicus is the most abundant rocky-reef fish in
Northern Patagonia (Galván et al., 2009), where it sustains commercial, recreational, and sport activities like scuba diving and hook-and-line and spear fishing. In offshore waters, it is caught by coastal and high-seas fleets, partly as bycatch in fisheries that target Argentine hake (Merluccius hubbsi) and Argentine red shrimp (Pleoticus muelleri). Commercial annual landings of $A$. patachonicus decreased between 1989 (14,509 metric tons) and 2013 (2462 metric tons) (MAGYP ${ }^{1}$ ).

Despite the large economic and recreational values of this species, there is little information about its reproductive ecology and behavior.

${ }^{1}$ MAGYP (Ministerio de Agricultura, Ganadería y Pesca). 2013. Total landings of marine catch by species and month. Ministerio de Agricultura, Ganadería y Pesca, Argentina. [Available at website, accessed November 2014.] 
What we know is that A. patachonicus is a longlived (maximum age recorded for fish $\sim 47 \mathrm{~cm}$ in total length was 40-41 years, see Rubinich, 2001), slowgrowing fish that reaches $65 \mathrm{~cm}$ in total length and $4 \mathrm{~kg}$ in weight (Irigoyen et al., 2008). It is a dioecious partial spawner and fertilization is external. The spawning season of this species extends between September and December off the coast of Buenos Aires province and in Northern Patagonia (Ciechomski and Cassia, 1976; Dell'Arciprete et al., 1987), where at least a fraction of its populations congregate in massive spawning aggregations (Irigoyen ${ }^{2}$ ). No data about its early life stages are available in the scientific literature.

In this study, the development of A. patachonicus from the egg stage to the posttransition juvenile stage (sensu Vigliola and Harmelin-Vivien, 2001) is described, and the distinctive features of its early life stages are compared with those of other species of Acanthistius. In addition, abundance and distribution patterns of larvae in the San Matías Gulf (SMG) and San José Gulf (SJG), in Northern Patagonia, and in adjacent waters are presented. Beyond a purely scientific interest, identification of the early stages of $A$. patachonicus will help to identify spatial and temporal patterns in reproduction and, in turn, will shed light on the location of spawning and nursery grounds for this species.

\section{Materials and methods}

\section{Collection of samples}

Eggs and yolk-sac larvae came from in vitro fertilization. Ripe adults were caught by trawling near the mouth of SMG $\left(41^{\circ} 45^{\prime} \mathrm{S} 63^{\circ} 28^{\prime} \mathrm{W}\right)$ on 11 November 1978, on board the RV Walther Herwig. Hydrated oocytes and sperm were mixed in a bucket with saltwater. Later, the fertilized eggs were washed and transferred to 2 -L buckets containing seawater at $18^{\circ} \mathrm{C}$. At approximately every $2 \mathrm{~h}$ over the course of a week, a variable number of eggs (between 16 and 39 eggs) and yolk-sac larvae (between 1 and 47 larvae) in different developmental stages were taken from the buckets and fixed in $5 \%$ formalin.

Aboard the RV Puerto Deseado on the Argentine shelf in November 2009, 41 ichthyoplankton samples were collected during the research cruise CONCACEN 2009, which was conducted by the Consejo Nacional de Investigaciones Científicas y Técnicas (CONICET) and the Servicio de Hidrografía Naval and also involved the Centro Austral de Investigaciones Científicas (CADIC) and Centro Nacional Patagónico (CENPAT) (Table 1; Fig. 1). Another 212 ichthyoplankton samples were

\footnotetext{
${ }^{2}$ Irigoyen, A. J. 2014. Personal commun. Centro Nacional Patagónico (CENPAT), Consejo Nacional de Investigaciones Científicas y Técnicas (CONICET), Puerto Madryn, Chubut, U9120ACD Argentina.
}

collected monthly during a 2-year survey that we conducted) aboard outboard motorboats in the SJG, covering a regular grid of 25 stations, from October 2011 through March 2012 and from September 2012 through April 2013 (Table 1; Fig. 1). No samples were available for January and November 2012 within the SJG. In addition, 105 ichthyoplankton samples were collected during 2 surveys, CC-01/08 and EH-05/11, conducted by the Instituto Nacional de Investigación y Desarrollo Pesquero (INIDEP, based in Mar del Plata, Argentina) in December 2008 and November 2011 aboard the RV Capitán Canepa and RV Eduardo Holmberg, respectively.

Ichthyoplankton tows were made with Hensen nets with mouth diameters of $70 \mathrm{~cm}$ (CONCACEN, SJG), multinets (CC-01/08) with square mouths $(50 \times 50 \mathrm{~cm})$, and bongo nets (EH-05/11) with mouth diameters of $60 \mathrm{~cm}$, all fitted with 300- $\mu \mathrm{m}$ mesh. General Oceanics ${ }^{3}$ (Miami), Hydro-Bios (Altenholz, Germany), and T.S.K. (Tsurumi-Seiki Co., Ltd., Yokohama, Kanagawa, Japan) flowmeters were mounted in the mouths of the nets to estimate the volume of filtered water. Towing speed ranged between 77 and $154 \mathrm{~cm} / \mathrm{s}$. During the research cruise CONCACEN 2009, 2 plankton tows (1 oblique tow (depths sampled: 5-172 m) and 1 horizontal tow (depths sampled: 1-20 m), were made at each station. During the 2 surveys in the SJG, tows were oblique tows (depths sampled: 7-52 m) or horizontal tows (depths sampled: $3-28 \mathrm{~m}$ ), depending on bottom depth, to increase the volume of water sampled. Horizontal tows were made a few meters below the surface when conducted aboard the RV Puerto Deseado and close to the bottom of the seafloor when conducted aboard motorboats within the SJG. Tows were horizontal during the survey CC-01/08 (depths sampled: 0-57 $\mathrm{m}$ ) and oblique during the survey EH-05/11 (depths sampled: 9-60 m). Maximum depth for each ichthyoplankton tow was recorded by depth sensors attached to the nets (Table 1). Water temperature was recorded with sensors coupled to the nets or with conductivity, temperature, and depth (CTD) sensors (during surveys CC-01/08 and EH-05/11, water temperature was recorded with a SBE 25 Sealogger CTD and SBE 19 SeaCAT Profiler CTD [Sea-Bird Electronics, Bellevue, WA], respectively).

Samples were fixed immediately after collection and preserved in 5\% formalin. Larval abundance was expressed as the number of larvae/ $1000 \mathrm{~m}^{3}$.

Only one posttransition juvenile was available, and it was used for the description of that stage. This specimen was caught near Mar del Plata, Argentina, in December 1963 in a bottom shrimp net at a depth of less than $30 \mathrm{~m}$. No further details were found on the label to identify the collection lot (ichthyoplankton collection, INIDEP, uncataloged).

\footnotetext{
${ }^{3}$ Mention of trade names or commercial companies is for identification purposes only and does not imply endorsement by the National Marine Fisheries Service, NOAA.
} 


\section{Table 1}

Data from stations where larvae of Acanthistius patachonicus were caught in the Argentine Sea during ichthyoplankton tows conducted by Consejo Nacional de Investigaciones Científicas y Técnicas (CONICET) as part of the CONCACEN (CONICETCADIC [Centro Austral de Investigaciones Científicas]-CENPAT [Centro Nacional Patagónico]) research cruise in 2009, during a survey that we conducted in the San José Gulf (SJG), 2011-2013, and during 2 surveys (CC-01/08 and EH-05/11) conducted by the Instituto Nacional de Investigación y Desarrollo Pesquero in 2008 and 2011. Three types of tows were used: horizontal subsurface tow (HSS), horizontal deep tow (HD), or oblique tow (O). For stratified stations, indicated with a plus sign $\left(^{+}\right)$, mean temperatures above and below the thermocline are provided in parentheses. w/d=missing data.

\begin{tabular}{|c|c|c|c|c|c|c|c|c|c|c|c|}
\hline $\begin{array}{l}\text { Research } \\
\text { cruise }\end{array}$ & Station & $\begin{array}{l}\text { Tow } \\
\text { type }\end{array}$ & Date & $\begin{array}{l}\text { Local } \\
\text { hour }\end{array}$ & Lat. S & Long. W & $\begin{array}{c}\text { Mean } \\
\text { water } \\
\text { temperature } \\
\left({ }^{\circ} \mathrm{C}\right)\end{array}$ & $\begin{array}{c}\text { Bottom } \\
\text { depth } \\
(\mathrm{m})\end{array}$ & $\begin{array}{l}\text { Maximum } \\
\text { depth } \\
\text { sampled } \\
\text { (m) }\end{array}$ & $\begin{array}{c}\text { Number } \\
\text { of } \\
\text { larvae }\end{array}$ & $\begin{array}{c}\text { Abundance } \\
\quad \text { (larvae } \\
/ 1000 \mathrm{~m}^{3} \text { ) }\end{array}$ \\
\hline CC-01/08 & 20 & HD & 17 Dec 2008 & 1120 & $42^{\circ} 28^{\prime}$ & $63^{\circ} 17^{\prime}$ & 10.5 & 62 & 52 & 10 & 56.98 \\
\hline \multirow[t]{7}{*}{ CONCACEN } & 7 & HSS & 16 Nov 2009 & 0106 & $40^{\circ} 45^{\prime}$ & $60^{\circ} 49^{\prime}$ & 12.7 & 54 & 8 & 1 & 5.37 \\
\hline & 7 & $\mathrm{O}$ & 16 Nov 2009 & 0135 & $40^{\circ} 45^{\prime}$ & $60^{\circ} 50^{\prime}$ & 12.7 & 55 & 20 & 3 & 25.52 \\
\hline & 8 & HSS & 16 Nov 2009 & 1234 & $41^{\circ} 11^{\prime}$ & $62^{\circ} 25^{\prime}$ & 13.9 & 52 & $\mathrm{w} / \mathrm{d}$ & 1 & 2.85 \\
\hline & 8 & $\mathrm{O}$ & 16 Nov 2009 & 1308 & $41^{\circ} 10^{\prime}$ & $62^{\circ} 27^{\prime}$ & 14.1 & 23 & 5 & 1 & 2.16 \\
\hline & 9 & $\mathrm{O}$ & 16 Nov 2009 & 1900 & $41^{\circ} 20^{\prime}$ & $63^{\circ} 00^{\prime}$ & 13.3 & 33 & 17 & 12 & 25.12 \\
\hline & 10 & HSS & 17 Nov 2009 & 0014 & $41^{\circ} 25^{\prime}$ & $63^{\circ} 19^{\prime}$ & 13.0 & 33 & 4 & 1 & 4.93 \\
\hline & 17 & $\mathrm{O}$ & 20 Nov 2009 & 1120 & $41^{\circ} 38^{\prime}$ & $63^{\circ} 40^{\prime}$ & 12.7 & 50 & 26 & 2 & 5.35 \\
\hline \multirow[t]{2}{*}{ EH-05/11 } & 583 & $\mathrm{O}$ & 26 Nov 2011 & 1849 & $40^{\circ} 51^{\prime}$ & $61^{\circ} 48^{\prime}$ & 17.0 & 35 & 28 & 111 & 750.62 \\
\hline & 591 & $\mathrm{O}$ & 28 Nov 2011 & 0935 & $40^{\circ} 31^{\prime}$ & $61^{\circ} 04^{\prime}$ & 14.3 & 44 & 41 & 19 & 174.82 \\
\hline \multirow[t]{8}{*}{ SJG survey } & 11 & $\mathrm{O}$ & 30 Nov 2011 & 1550 & $42^{\circ} 17^{\prime}$ & $64^{\circ} 21^{\prime}$ & 14.5 & 72 & $\mathrm{w} / \mathrm{d}$ & 2 & 16.88 \\
\hline & 15 & $\mathrm{HD}$ & 19 Dec 2011 & 1657 & $42^{\circ} 15^{\prime}$ & $64^{\circ} 15^{\prime}$ & 16.0 & 31 & $\mathrm{w} / \mathrm{d}$ & 1 & 15.44 \\
\hline & 5 & $\mathrm{O}$ & 20 Dec 2011 & 1707 & $42^{\circ} 17^{\prime}$ & $64^{\circ} 27^{\prime}$ & 16.0 & 34 & $\mathrm{w} / \mathrm{d}$ & 1 & Present \\
\hline & 1 & HD & 12 Mar 2012 & 1326 & $42^{\circ} 19^{\prime}$ & $64^{\circ} 33^{\prime}$ & 16.7 & 19 & 13 & 1 & 9.26 \\
\hline & $23^{+}$ & $\mathrm{O}$ & 14 Mar 2012 & 1124 & $42^{\circ} 21^{\prime}$ & $64^{\circ} 09^{\prime}$ & $(17.1-16.2)$ & 58 & 50 & 1 & 4.80 \\
\hline & $21^{+}$ & $\mathrm{O}$ & 14 Mar 2012 & 1244 & $42^{\circ} 17^{\prime}$ & $64^{\circ} 09^{\prime}$ & $(17.0-16.6)$ & 55 & 44 & 1 & 5.39 \\
\hline & 20 & HD & 23 Dec 2012 & 1243 & $42^{\circ} 15^{\prime}$ & $64^{\circ} 15^{\prime}$ & 14.0 & 24 & $\mathrm{w} / \mathrm{d}$ & 2 & 16.53 \\
\hline & $17^{+}$ & $\mathrm{O}$ & 14 Feb 2013 & 1453 & $42^{\circ} 19^{\prime}$ & $64^{\circ} 15^{\prime}$ & $(15.9-15.4)$ & 65 & 43 & 1 & 32.46 \\
\hline
\end{tabular}

\section{Description of early stages}

In all, 170 eggs, 48 yolk-sac larvae $1.1-2.9 \mathrm{~mm}$ in body length (BL), 31 preflexion larvae (2.2-6.1 mm BL), 16 flexion larvae (4.9-7.6 $\mathrm{mm} \mathrm{BL}), 4$ postflexion larvae (7.2-8.4 $\mathrm{mm} \mathrm{BL}$ ), and 1 posttransition juvenile (13.1 $\mathrm{mm} \mathrm{BL}$ ), were used to describe morphometrics, meristics, pigmentation (melanophores), and head spination according to the series method of Neira et al. (1998). Description of eggs was based on the typical identification characters: egg shape and size, presence and number of oil globules, perivitelline space width, and distinctive features of the yolk and oil droplet. The measurements of larvae, categories for body proportions, and the terminology for morphometrics followed Neira et al. (1998): body length (BL), distance from the tip of the snout to the notochord tip (in preflexion and flexion larvae), and to the posterior margin of the hypural bones (postflexion larvae and posttransition juvenile); eye diameter (ED), longest diameter of the eye; snout length (SnL), distance from the tip of the snout to the anterior margin of the eye; head length, distance from the tip of the snout to the posterior margin of the opercle; body depth, vertical distance on pectoral fin base; preanal length, distance from the tip of the snout to the anus.

In the following descriptions, larval length always refers to BL, and morphometric measurement was calculated as a proportion of BL, with the exception of ED and $\mathrm{SnL}$, which were calculated as a proportion of head length. Specimens were measured to the nearest 0.1 $\mathrm{mm}$ from digital images that were taken with a Cybershot DSC-W200 camera (Sony Corp., Tokyo) coupled to a Wild M3 stereomicroscope (Leica Geosystems AG, St. Gallen, Switzerland) and processed with the AxioVision LE software, vers. 4.1 (Zeiss, Oberkochen, Germany). Possible shrinkage effects were not considered in the measurements. Whenever possible, the number of myomeres, spines, and rays of dorsal, anal, caudal, pectoral, and pelvic fins were recorded. All measures and meristic counts were made on the left side of the body. To describe head spination and the sequence of opercular development, as well as other osteological features, 21 preflexion, 11 flexion, and 3 postflexion larvae and 


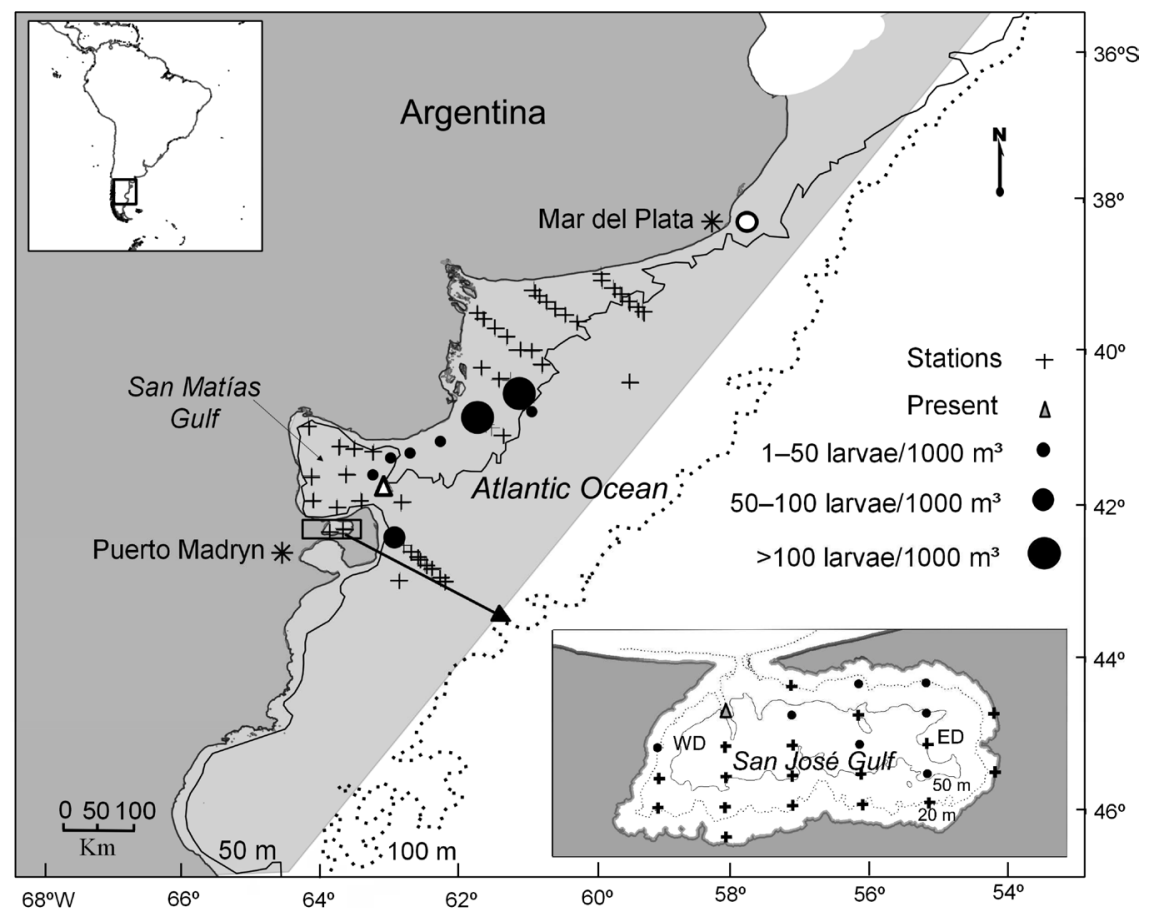

Figure 1

Distribution of larvae of Acanthistius patachonicus collected on the Argentine shelf, 2008-2013. The shaded area of water indicates the approximate distributional range for this species determined by Cousseau and Perrotta (2000). Only the oceanographic stations within the area of this range were plotted. The diameters of dots, classified into 3 categories, are proportional to larval abundance at each station. The open triangle indicates the position where ripe adults were caught for the fertilization experiment. The open circle indicates the area where the posttransition juvenile was caught. WD and ED indicate the western and eastern domains within the San José Gulf (sensu Amoroso and Gagliardini [2010]).

the posttransition juvenile were cleared and double stained with alcian blue and alizarin, according to Potthoff (1984) and Taylor and Van Dyke (1985). Different development stages were illustrated according to the guidelines of Trnski and Leis (1991).

\section{Results}

\section{Eggs and yolk-sac larvae}

The pelagic eggs in A patachonicus were spherical, with a mean diameter of $1.1 \mathrm{~mm}$ (standard deviation [SD] 0.1), lacked pigmentation, and had a single, pale yellow oil globule (mean diameter: $0.2 \mathrm{~mm}$ [SD 0.1]) and a clear, segmented yolk (Fig. 2). The thin perivitelline space (mean: $0.2 \mathrm{~mm}$ [SD 0.1]) had no pigmentation, and the chorion was translucent.

Recently hatched larvae had a small, ovoid yolk sac that represented $\sim 17 \%$ of $\mathrm{BL}$, with 1 oil globule located anteriorly. The eyes were unpigmented and the mouth was not yet formed at this stage (Fig. 3A).

\section{Morphology and development of larvae and posttransition juveniles}

Four larvae were deposited as vouchers in the ichthyological collection of the Centro Nacional Patagónico: CNPICT 2009/21, flexion, broken larva, $41^{\circ} 25^{\prime} \mathrm{S}$, $63^{\circ} 19^{\prime} \mathrm{W}$; CNPICT 2009/22-1, postflexion, $7.6 \mathrm{~mm}$, $41^{\circ} 20^{\prime} \mathrm{S}, 63^{\circ} 00^{\prime} \mathrm{W}$; CNPICT $2009 / 22-2$, flexion, $7.5 \mathrm{~mm}$, $41^{\circ} 20^{\prime} \mathrm{S}, 63^{\circ} 00^{\prime} \mathrm{W}$; CNPICT $2011 / 7$, preflexion, $5.0 \mathrm{~mm}$, $42^{\circ} 17^{\prime} \mathrm{S}, 64^{\circ} 21^{\prime} \mathrm{W}$.

Body shape The smallest preflexion larva collected $(2.2 \mathrm{~mm})$ had round and incipiently pigmented eyes; the yolk was completely absorbed, and the mouth was terminal and open (Fig. 3B). Notochord flexion began at about $4.9 \mathrm{~mm}$ and was completed by $7.6 \mathrm{~mm}$. The coiled digestive tract was already evident at preflexion.

Larval development was a gradual process. However, some discontinuities in body proportions were evident between larvae of $2.2-3.0 \mathrm{~mm}$ and larger individuals (Fig. 4). Head length was moderate, averaging $23 \%$ BL in larvae $<4.2 \mathrm{~mm}$, and was $28 \%-35 \%$ in larvae 

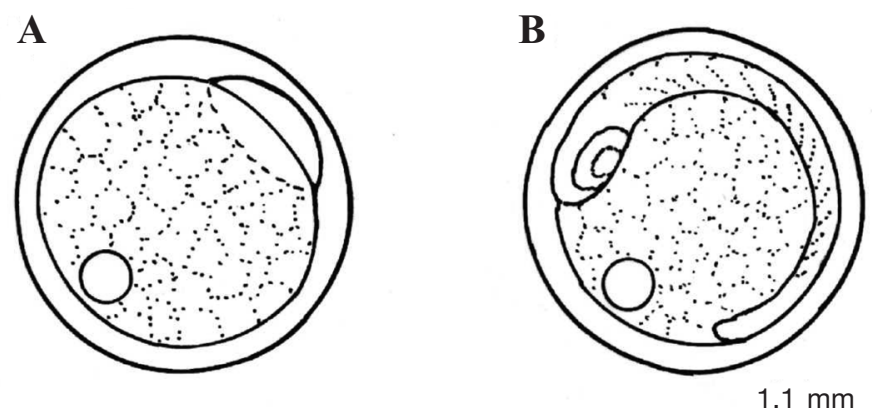

\section{Figure 2}

Illustrations of stages of eggs of Acanthistius patachonicus: (A) early stage with blastodermal cup, $12 \mathrm{~h}$ after fertilization, and (B) late stage with embryo surrounding the yolk (approximately $270^{\circ}$ ), $60 \mathrm{~h}$ after fertilization. The diameter of the eggs is $1.1 \mathrm{~mm}$.

4.2-8.4 $\mathrm{mm}$; it was $34 \%$ in the posttransition juvenile and reached $39 \%$ in adults (reference values for adults from Nakamura et al., 1986) (Fig. 4A). Body depth was moderate, with means of $22-26 \% \mathrm{BL}$ in larvae $<4.2 \mathrm{~mm}$ and of $27-33 \%$ in larvae $4.2-8.4 \mathrm{~mm}$; it was $35 \%$ in the posttransition juvenile and $28 \%$ in adults (Fig. 4B). The preanal length was moderate in larvae $<4.2 \mathrm{~mm}$ (44-46\% BL) and long in larger larvae (54$62 \%)$, posttransition juveniles $(62 \%)$, and adults $(57 \%)$ (Fig. 4C).

In the head, SnL increased between $30 \%$ and $40 \%$ and remained rather stable in larger larvae and in the posttransition juvenile (Fig. 5A), and ED decreased markedly (between $41 \%$ and $24 \%$ [Fig. 5B]). The mouth size increased slightly with development. By $\sim 6 \mathrm{~mm}$, the larvae had conic teeth in the upper jaw.

The posttransition juvenile stage was identified by its morphological similarities with the morphological features of adults (Fig. 3G). The snout was short and rounded. The mouth was terminal and reached the anterior edge of the eye. Both jaws showed only caniniform teeth.

Development of meristic characters Most of the meristic features of larvae of $A$. patachonicus developed between $\sim 6$ and $8.4 \mathrm{~mm}$ (flexion and postflexion stages) (Table 2). Larvae had 23-26 myomeres (mode: 25 myomeres), 7-12 preanal and 13-18 postanal; the myomere formula did not change with development. Preflexion larvae had only an undifferentiated finfold and paired pectoral-fin buds (Fig. 3, B-D). Fin-ray formation started with the development of dorsal, pectoral, caudal, and pelvic fins during flexion and was completed between 8.4 and $13.1 \mathrm{~mm}$; fin elements reached their full complement in the posttransition juvenile. All fin spines were smooth.

Three branchiostegal rays were present at $4.4 \mathrm{~mm}$; by $6.8 \mathrm{~mm}$, 6 rays were formed, and, by $7.7 \mathrm{~mm}$, the full complement of 7 rays was present (Table 2).
Fin formation The finfold in yolk-sac and preflexion larvae was symmetrical around the tip of the notochord (Fig. 3, A-C). By $5.5 \mathrm{~mm}$, the first ray ventral to the notochord appeared, and in larger larvae the number of rays were added nearly symmetrically in the upper and lower lobes (Fig. $3 \mathrm{D})$. In postflexion larvae, the caudal fin had a rounded, homocercal outline with about 8 rays in each of the upper and lower lobes. The adult complement of 9 branched rays in the upper lobe and 8 branched rays in the lower lobe developed by $13.1 \mathrm{~mm}$ (Table 2; Fig. 3G).

Pectoral fin buds were present in the smallest preflexion larvae (Fig. 3B). By $\sim 6 \mathrm{~mm}$, the upper 2-5 pectoral-fin rays, 1 pelvic-fin spine, and 3 pelvic-fin rays were present (Fig. 3E). Rays in the pectoral fin developed ventrally (Fig. $3 \mathrm{~F}$ ).

The undifferentiated dorsal finfold extended from the nape to the caudal region in larvae $<6.1$ $\mathrm{mm}$. The dorsal-fin spines and rays started to appear during flexion and were added in an anterior to posterior sequence. Between 6.1-6.9 mm, 2 spines had already formed, and between $7.0-7.6 \mathrm{~mm}$ the 3 first rays had formed. Anal-fin rays were not yet developed in larvae $<8.4 \mathrm{~mm}$ (Table 2; Fig. 3F).

Nearly full complements of fin spines and rays were present as early as the posttransition juvenile stage: the pelvic fin had 1 spine and 4 rays; the pectoral fin had 17 rays; the dorsal fin had 12 spines and 16 rays; and the anal fin had 2 spines and 9 rays (Table 2; Fig. $3 G)$. The first and second dorsal spines were shorter than the third and fourth spines. The first 2 dorsal interneurals were separate and supported the first 2 spines. The first anal spine was shorter than the second spine (Fig. 3G). The spines in the anal fin were supported by 2 separate interhaemals.

Axial skeleton Ossification of the vertebral column proceeded posteriorly from the first vertebra. This process began at $6.1 \mathrm{~mm}$; by $7.0 \mathrm{~mm}, 11$ vertebrae were ossified, and by $7.7 \mathrm{~mm}$ all except for the last 8 vertebrae and the urostyle were ossified. Each neural spine and arch ossified first, followed by the centrum and then by the haemal arch and spine. Ossification of the pleural ribs was not evident in the posttransition juvenile studied.

The caudal complex in the posttransition juvenile was the typical perciform type (Fig. 6). The caudal skeleton had 3 epurals, the urostyle, a small uroneural dorsal to the urostyle, 4 hypurals, and 2 autogenous haemal arches on the antepenultimate and penultimate vertebrae. There were 15 branched, segmented rays supported by the hypurals: 6 ventrally on hypurals 1 and 2 and 9 dorsally on hypurals 3 and 4 . Four dorsal and 7 ventral raylets were adjacent to the segmented rays.

Head spination and opercular complex development The number and location of head spines in A. patachonicus were of great taxonomic value and helpful in the construction of the larval developmental series. All head spines were smooth. 
A

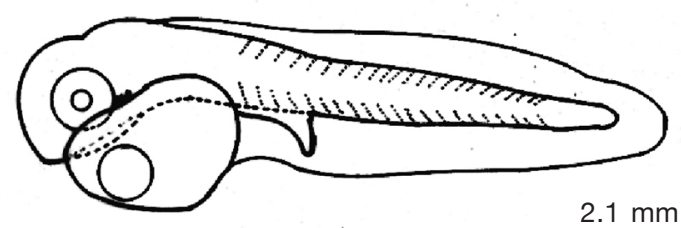

B

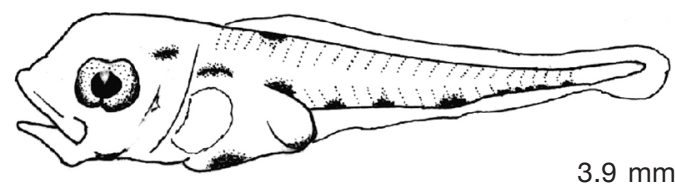

C

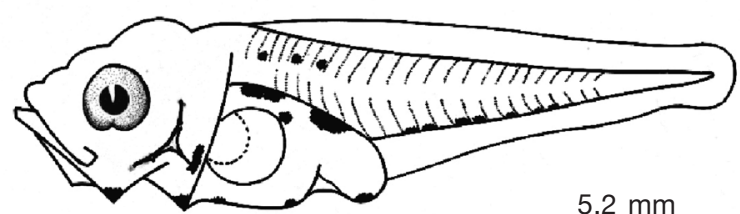

D

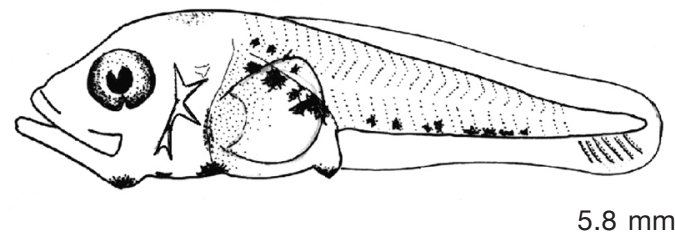

$\mathbf{E}$

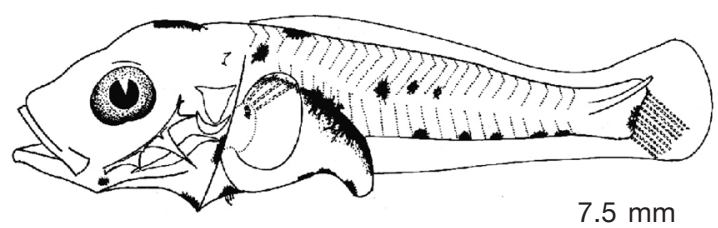

F

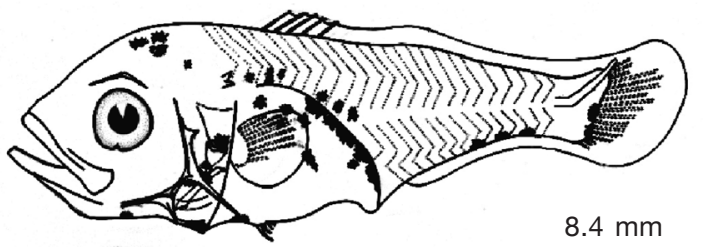

G

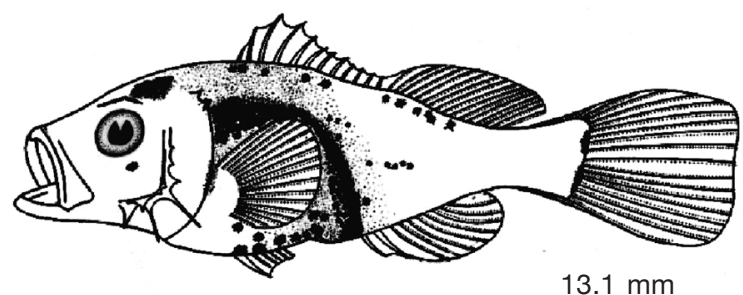

Figure 3

Illustrations of early stages of Acanthistius patachonicus: (A) yolk-sac larva (2.1 mm body length [BL]); preflexion at (B) 3.9 $\mathrm{mm} \mathrm{BL}$, (C) $5.2 \mathrm{~mm} \mathrm{BL}$, and (D) $5.8 \mathrm{~mm} \mathrm{BL}$; (E) flexion $(7.5 \mathrm{~mm}$ $\mathrm{BL})$; (F) postflexion ( $8.4 \mathrm{~mm} \mathrm{BL})$; and $(\mathbf{G})$ posttransition juvenile (13.1 mm BL).
In early preflexion larvae, the preopercle was a partially ossified triangular plate with a sharp point where a spine would develop later. Its anterior margin was slightly thickened (Fig. 7A). In advanced preflexion larvae, the larger preopercle ossified completely, and its anterior margin became thicker. Two minute foramina and a well-defined posteroventral-oriented spine developed on the posterior margin of the preopercle (Fig. 7B). The opercle ossified partially and had a thickened margin.

In early flexion larvae, 2 anterior and 3 posterior preopercular spines were present (Fig. $7 \mathrm{C})$. The middle spine was the largest, followed in size by the dorsal spine. The ventral spine was minute. The triangular-shaped opercle ossified completely and articulated with the hyomandibular at this stage. The subopercle was incipient and located below the opercle; the interopercle was situated below the middle preopercular spine.

In advanced flexion, the preopercle maintained its overall shape and increased in size (Fig. 7D). The opercle developed an anterior projection and a posterior spine. The U-shaped subopercle ossified, occupying the whole space between the opercle and the interopercle. The supracleithrum, bearing 1 spine, was already evident at this stage. By late flexion, all elements were completely ossified (Fig. 7E). The anterior preopercular margin had 3 spines; the middle one was the largest. The long, midposterior preopercular spine extended beyond the cleithrum. The interopercle reached the ventral posterior preopercular spine.

In postflexion (Fig. $7 \mathrm{~F}$, the posttransition juvenile), the preopercle formed an approximate right angle with 3 small, anterior spines and 6 posterior spines; the 4 lower posterior spines were larger (the spine at the angle was largest) and 3 of these spines were ventrally oriented. The supracleithrum had 3 spines, and the interopercle had 2 spines. The opercle had 3 spines - the one in the middle forming a middle opercular ridge. The V-shaped subopercle had 4 acute vertices.

In larvae $>7.5 \mathrm{~mm}$, there was a supraocular crest and 2 posttemporal spines (Fig. 3, E-G).

Pigmentation pattern Pigmentation pattern in formalin-preserved larvae of A. patachonicus consisted of a few melanophores in specific positions. Yolk-sac larvae were unpigmented (Fig. 3A). In 3.9-mm preflexion larvae, pigmentation on the head consisted of one external spot at the angle of the lower jaw and another posterior and dorsal to the eye (Fig. 3B). A small internal spot also appeared at the base of the pectoral buds anterior to the cleithrum (Fig. 3C). In flexion and postflexion 


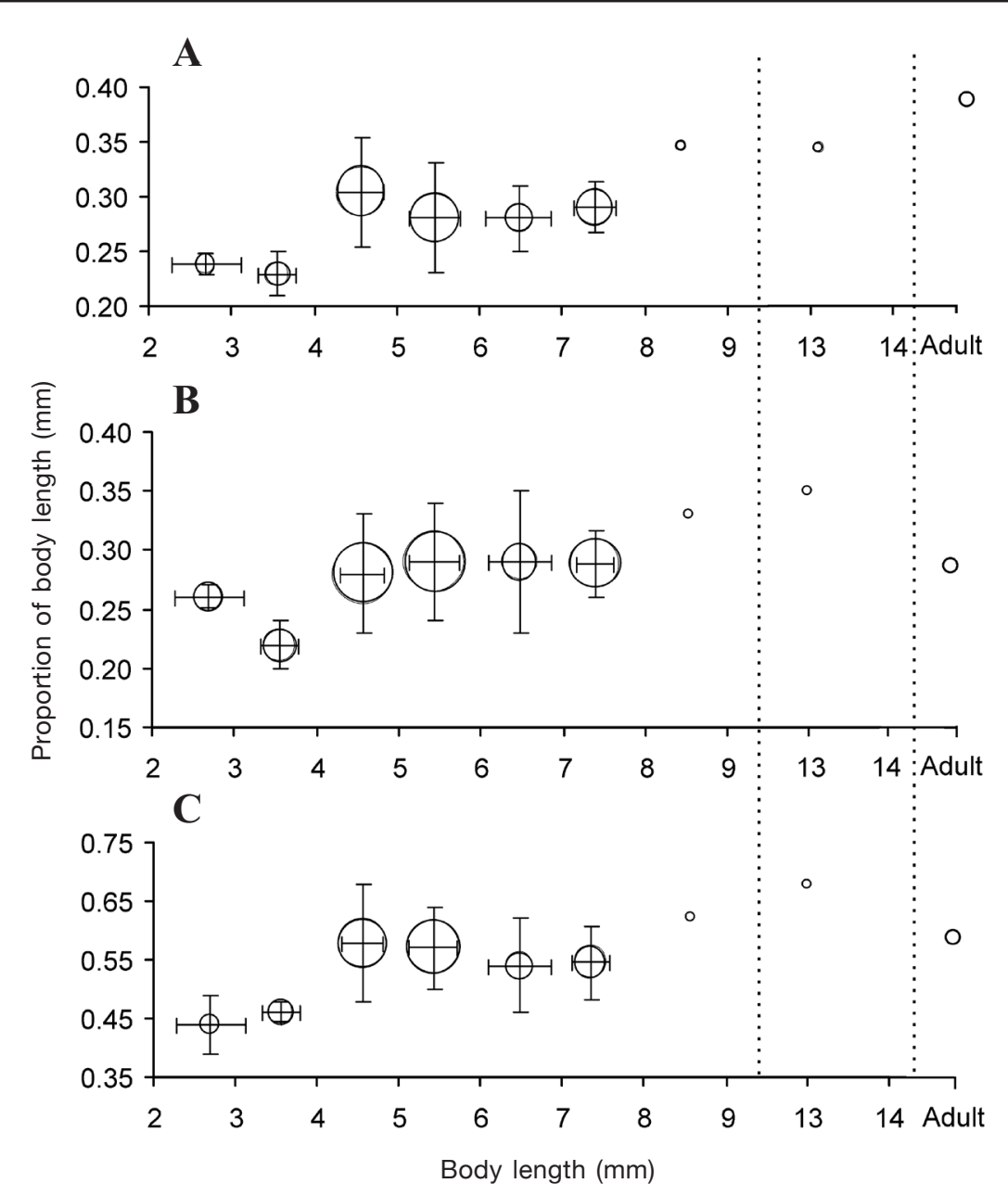

Figure 4

Body proportions of Acanthistius patachonicus (trunk region) examined for this study and collected on the Argentine shelf, 2008-2013: (A) head length, (B) body depth, and (C) preanal length. Bubble size in each plot is proportional to the number of larvae in each size range (from 1 to 14 larvae). Solid bars on bubbles indicate standard deviations for mean body lengths (BLs) and for the proportions of BL. Adult proportions were taken from Nakamura et al. (1986). Vertical dotted lines indicate discontinuities along the $x$-axis.
A few, small isolated spots on the anterolateral side of the trunk were present in larvae ranging between $\sim 5$ and $7.5 \mathrm{~mm}$ (Fig. 3, C-E). Pigmentation along the midventral line consisted of a short series of 3-4 small spots (Fig. 3, B-F). As the caudal rays developed, less prominent spots appeared in the middle of the hypural margin (Fig. 3, E and F).

\section{Abundance and distribution of larvae}

Larvae of A. patachonicus were collected from mid-November to midMarch (during the years described previously in this section), between $40^{\circ} 31^{\prime} \mathrm{S}$ and $42^{\circ} 28^{\prime} \mathrm{S}$, somewhere above the bottom in water up to 52 $\mathrm{m}$ deep (Table 1; Fig. 1). At stations where larvae were captured, mean water temperature ranged broadly between $10.5^{\circ} \mathrm{C}$ and $17.9^{\circ} \mathrm{C}$. Overall, both the frequency of occurrence and larval density were low at stations where larvae were caught: between 1 (2.16 larvae/1000 $\left.\mathrm{m}^{3}\right)$ and 111 larvae (750.62 larvae/1000 $\mathrm{m}^{3}$ ) were collected in shallow tows to the east of the mouth of the SMG and within the SJG, predominantly in the eastern domain (sensu Amoroso and Gagliardini, 2010) (Table 1). The distribution pattern of small preflexion larvae matched the overall distribution of larvae of $A$. patachonicus in the study area.

\section{Discussion}

In this study, the eggs and yolk-sac larvae came from a fertilization experiment, and that origin confirmed their species identity. Morphological features, including the developlarvae (Fig. 3, E and F), a group of stellate external melanophores was located in the parietal region, and another internal group was located beneath the longest preopercular spine. The parietal patch of melanophores increased in size in the posttransition juvenile (Fig. 3F). A large internal melanophore was present at the base of the cleithrum in advanced preflexion larvae (Fig. 3, C-F).

Considerable internal pigmentation developed in the dorsal area of the gut cavity and gas bladder, primarily on the surface of the viscera. The number of melanophores over the gut increased with development. A few internal melanophores also were present at the ventral margin of the gut (Fig. 3, B-F). ment of the opercular complex and head spination, the sequence of development of meristic characters, and the position and relative size of the melanophores in preflexion, flexion, and postflexion larvae, allowed reconstruction of a developmental series and identification of the remaining individuals studied as $A$. patachonicus.

At present, the larval development has been described for only 2 of the 11 species of Acanthistius. Baldwin and Neira (1998) studied the larvae of the western wirrah (A. serratus) from Western Australia, and Brownell (1979) described the eggs and larvae of the koester (A. sebastoides) from the southern coast of Africa. For our study, we considered that the 


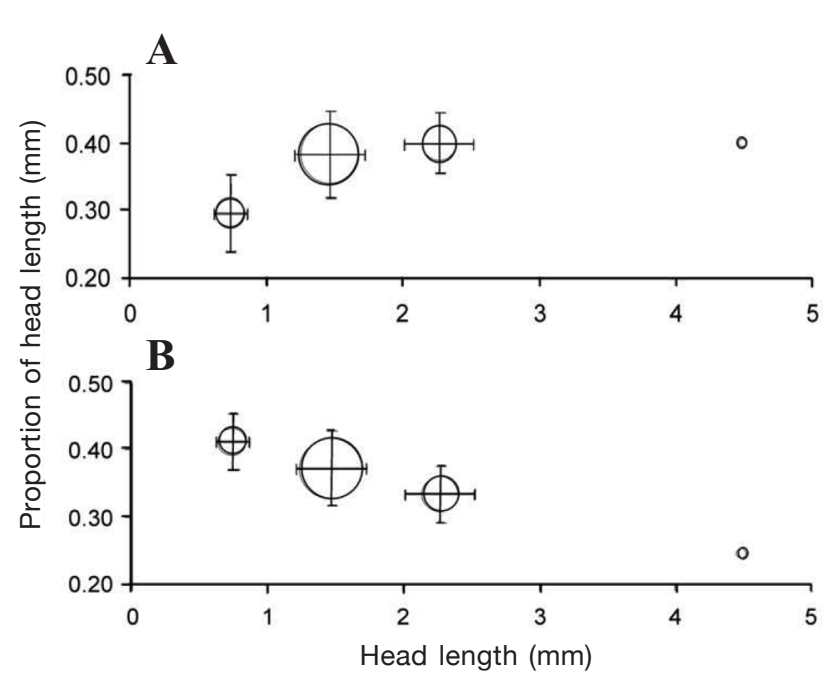

Figure 5

Body proportions of Acanthistius patachonicus (head region) examined for this study and collected on the Argentine shelf, 2008-2013: (A) snout length and (B) eye diameter. Bubble size in each plot is proportional to the number of larvae in each size range (from 1 to 30 larvae. Solid bars on bubbles indicate standard deviations for mean head lengths (HLs) and for the proportions of HL.

"Perciform Species 1" in Brownell (1979) was A. sebastoides (Brownell4; Baldwin and Neira, 1998; Heemstra, 2010).

Some morphological characteristics of the early stages of $A$. patachonicus were similar to those of

\footnotetext{
${ }^{4}$ Brownell, C. L. 1979. Personal commun. Oceanic Institute, Waimanalo, HI 96795.
}

other species in this genus. The eggs, for example, resembled those of koester, which has pelagic eggs about $0.9 \mathrm{~mm}$ in diameter, with a single $0.2-\mathrm{mm}$ oil globule (Brownell, 1979). The number of myomeres, spines and rays in $A$. patachonicus were in the same range as those from larvae of other Acanthistius species (Brownell, 1979; Baldwin and Neira, 1998). The preopercular spines in A. patachonicus were as conspicuous as those found in western wirrah and koester, and the preopercular spine at the posterior angle was the largest one among all 3 species. Two posttemporal spines were present in western wirrah and $A$. patachonicus.

However, other characteristics, including pigmentation and the sequence of formation of the fin elements, differed among the species. The number of pigmentation spots in the head and trunk of $A$. patachonicus was lower than the number observed in larvae of both the western wirrah and koester (Brownell, 1979; Baldwin and Neira, 1998). Notochord flexion in A. patachonicus and western wirrah began at a similar size but ended at a larger size in A. patachonicus (4.9-7.5 mm; western wirrah, 4.1$5.3 \mathrm{~mm}$ : Baldwin and Neira, 1998). In A. patachonicus, the anal-fin rays began to form after notochord flexion, but in western wirrah the dorsal- and analfin soft rays began to form simultaneously during flexion (Baldwin and Neira, 1998), although anal-fin development was not complete until the postflexion stage (by $7.5 \mathrm{~mm}$ ).

Undoubtedly, the most relevant feature that allowed reconstruction of the developmental series and linkage from the posttransitional stage to the adult stage in $A$. patachonicus was the opercular complex. It was possible to track the morphological changes observed in the preopercle, opercle, subopercle, interopercle, and supracleithrum and to track the development of spination in those structures, from the initial development

\section{Table 2}

Development of meristic characters in Acanthistius patachonicus. Data for adults were obtained from Nakamura et al. (1986) and Irigoyen et al. (2008). Asterisks indicate the size ranges at which notochord flexion occurs. w/d=missing data. $N=$ number of specimens.

\begin{tabular}{|c|c|c|c|c|c|c|c|c|c|c|c|c|c|}
\hline \multirow{2}{*}{$\begin{array}{l}\text { Body length } \\
\text { range (mm) }\end{array}$} & \multirow[b]{2}{*}{$N$} & \multicolumn{2}{|c|}{ Dorsal fin } & \multicolumn{2}{|c|}{ Pelvic fin } & \multirow{2}{*}{$\begin{array}{l}\text { Pectoral- } \\
\text { fin rays }\end{array}$} & \multicolumn{2}{|c|}{ Anal fin } & \multirow{2}{*}{$\begin{array}{c}\text { Branchio- } \\
\text { stegal } \\
\text { rays }\end{array}$} & \multirow{2}{*}{$\begin{array}{c}\text { Total } \\
\text { myomeres }\end{array}$} & \multirow{2}{*}{ Vertebrae } & \multicolumn{2}{|c|}{ Caudal-fin rays } \\
\hline & & Spines & Rays & Spines & Rays & & Spines & Rays & & & & Upper & Lower \\
\hline $2.0-2.9$ & 3 & - & - & - & - & - & - & - & - & 25 & - & - & - \\
\hline $3.0-3.9$ & 4 & - & - & - & - & - & - & - & - & 25 & - & - & - \\
\hline $4.0-4.9$ & 14 & - & - & - & - & - & - & - & $3-4$ & $22-25$ & - & - & - \\
\hline $5.0-5.9 *$ & 16 & - & - & - & - & - & - & - & $3-4$ & $23-26$ & - & - & - \\
\hline $6.0-6.9 *$ & 5 & II & - & - & 3 & $2-5$ & I & - & $2-6$ & $24-25$ & $5-13$ & $3-6$ & $3-9$ \\
\hline $7.0-7.9^{*}$ & 8 & II-V & 3 & - & 3 & $3-7$ & I & - & $4-7$ & $23-26$ & $10-16$ & $3-8$ & $3-8$ \\
\hline $8.0-8.9$ & 1 & VI & - & - & - & - & - & - & - & - & - & 8 & 7 \\
\hline $13.0-13.9$ & 1 & XII & 16 & I & 4 & 17 & II & 9 & 7 & - & 25 & 9 & 8 \\
\hline Adults & w/d & XII-XIII & $15-16$ & I & 5 & 17 & II-III & $8-10$ & 7 & - & 25 & 9 & 8 \\
\hline
\end{tabular}




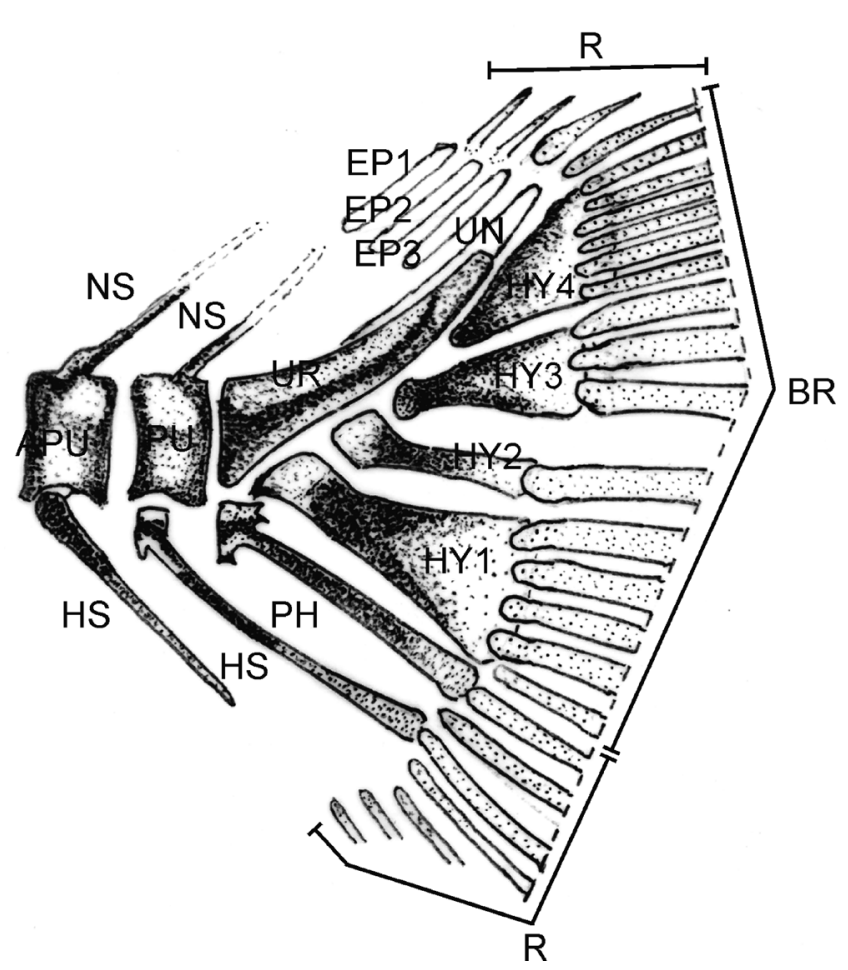

Figure 6

Illustration of the caudal skeleton of the single posttransition juvenile (13.1 $\mathrm{mm}$ in body length) of Acanthistius patachonicus that was examined for this study; this specimen was caught near Mar del Plata, Argentina, in December 1963: raylets (R), epurals 1-3 (EP), uroneural (UN), neural spines (NS), hypurals 1-4 (HY), branched rays (BR), antepenultimate vertebra (APU), penultimate vertebra (PU), urostyle (UR), haemal spines (HS), and parahypural (PH).

of the preopercle in preflexion larvae $<3.1 \mathrm{~mm} \mathrm{BL}$. In the larger posttransition juvenile (13.1 $\mathrm{mm} \mathrm{BL})$, the preopercle and the opercle allowed linkage from the postflexion stage to the adult stage, because both bones in this juvenile matched the osteological description for adult fish (Gosztonyi and Kuba ${ }^{5}$; Irigoyen et al., 2008).

Head spination and pigmentation were useful for distinguishing larvae of $A$. patachonicus from other, morphologically somewhat similar species described for the Argentine Sea (Sánchez, 1991). Rough scad (Trachurus lathami) has a higher number of spines on the preopercular margin (Sánchez-Ramírez and FloresCoto, 1993), and larvae of cabrilla (Sebastes oculatus) have visible parietal spines by $5.3 \mathrm{~mm}$ BL (Sánchez and Acha, 1988). The pigmentation pattern of larvae of $A$. patachonicus also differed from those of rough scad, cabrilla, and wreckfish (Polyprion americanus).

${ }^{5}$ Gosztonyi, A. E., and L. Kuba. 1996. Atlas de huesos craneales y de la cintura escapular de peces costeros patagónicos. Inf. Tec. 4, 29 p. Fundacion Patagonia Natural, Chubut, Patagonia, Argentina. [Available at website.]
Rough scad has numerous melanophores on the head and along the dorsal and ventral midlines (Sánchez-Ramírez and Flores-Coto, 1993), cabrilla has heavy pectoral-fin pigmentation throughout larval development (Sánchez and Acha, 1988), and wreckfish has strongly pigmented larvae with stellate melanophores all over the body (Sparta, 1939). The wreckfish also has a large, oblique mouth that reaches the posterior margin of the eye, another difference from A. patachonicus (Fig. 3). Finally, larvae of dusky grouper (Epinephelus marginatus) have serrate and pigmented dorsal and pelvic spines that distinguish this species from $A$. patachonicus (Cunha et al., 2013).

The spawning season of $A$. patachonicus lasts for about 4 months (September-December) during the austral spring, between $\sim 36^{\circ} \mathrm{S}$ and $43^{\circ} \mathrm{S}$. The presence of its planktonic larvae, which were collected from November through March, 2008-2013, was slightly delayed in relation to the spawning season. Because the surveys conducted were not specifically designed to study the spatial or temporal distribution of this species outside of the SJG where a 2-year systematic survey was conducted, only limited inference about their distribution and abundance patterns can be derived from the data available. Analyzing an extensive database of fisheries surveys, Irigoyen (2006) reported high concentrations of $A$. patachonicus in shelf areas (depths: $<90 \mathrm{~m}$ ) during the reproductive season. The occurrence of larvae in coastal areas, to the east and north of the mouth of the SMG, was coincident with the reported distribution patterns of ripe adults (Irigoyen ${ }^{2}$ ).

Although A. patachonicus is the most abundant rocky-reef fish in Northern Patagonia, between $\sim 40^{\circ} \mathrm{S}$ and $45^{\circ} \mathrm{S}$ (Irigoyen et al., 2008), its larvae have been scarce: overall, they were present in only $17 \%$ of the tows conducted between November and March in 2009-2013. Only a single individual was captured in most of the tows, with few exceptions (Table 1, Fig. 1). This patchy distribution is consistent with the occurrence of spawning aggregations of adults of this species (Irigoyen ${ }^{2}$ ). However, the small size of the larvae collected may also indicate a short pelagic life. Indeed, larvae longer than $8.4 \mathrm{~mm} \mathrm{BL}$ were not found (see also Acha et al., 2012), and the juvenile fish that was $13.1 \mathrm{~mm}$ BL had already metamorphosed, indicating that individuals of this species could adopt a demersal habit at around $13 \mathrm{~mm} \mathrm{BL}$.

Similarly, the mean planktonic larval duration of some serranid fishes of the genera Paralabrax, Epinephelus, and Serranus, for example, ranges between 18 and 33 days (McClean, 1999; Macpherson and Raventos, 2006; Allen and Block, 2012), and 3 species of Paralabrax settle to the bottom as larvae between 9.1 and $10.2 \mathrm{~mm}$ BL (Allen and Block, 2012). Further, Baldwin and Neira (1998) stated that western wirrah would settle between 10.5 and $23.0 \mathrm{~mm} \mathrm{BL}$, and Brownell (1979) registered one koester taking up a 


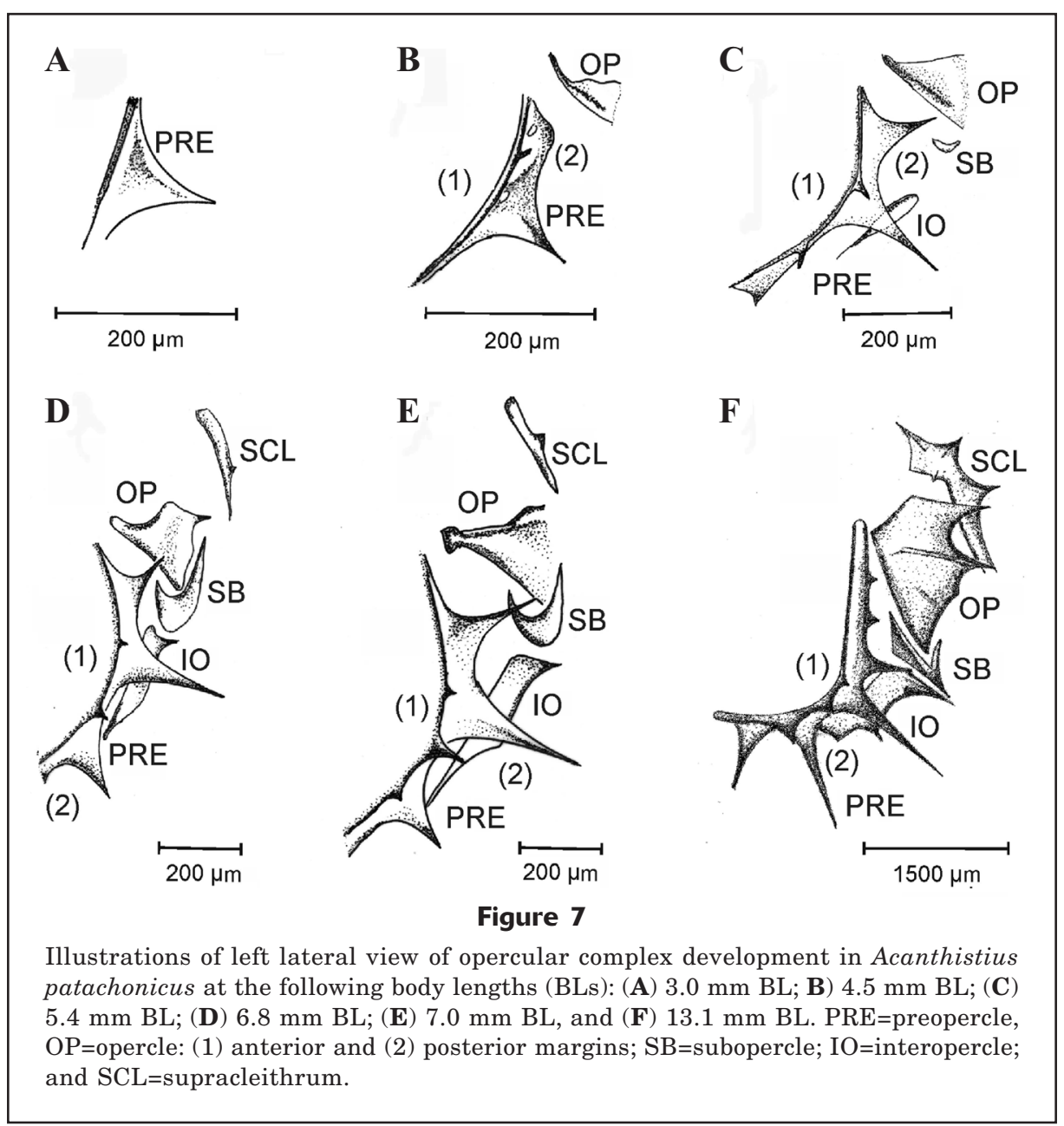

benthic lifestyle and changing its coloration by a standard length of $9.0 \mathrm{~mm}$.

Alternatively, another explanation may be avoidance of the plankton nets by larger larvae, especially during daylight hours. Hence, other sampling techniques (e.g., the use of light traps, trawl nets, or video stations; Harasti et al., 2014) and survey designs specific to collection of larger fish (e.g., between 8.4 and 13.1 $\mathrm{mm} \mathrm{BL}$ ) should be used to sample fish and determine more precisely the size at settlement.

The identification of the early stages of A. patachonicus is a first step toward a better understanding of its reproductive behaviour and ecology, connectivity patterns, and dispersal capabilities, all of which in turn will serve as fundamental pieces of knowledge for the proper management of its populations in the Argentine Sea.

\section{Acknowledgments}

We want to thank M. López, P. Fiorda, R. Hernández Moresino, L. Getino, G. Trobbiani, N. Ortíz, D. Remenar, I. D'ercole, and the crews of the RV Puerto Deseado, RV Capitán Cánepa, and RV Eduardo Holmberg for their help during surveys. L. Machinandiarena and M. R. Marín collaborated on laboratory work and data analysis, respectively. J. Dignani designed and calibrated depth and temperature sensors. C. Pipitone provided useful literature. C. Guerrero helped with revisions of figures. A. Gosztonyi and 2 anonymous reviewers made useful comments on an earlier version of this article, and N. Glembocki helped with the English language. CONICET partially funded the research cruise CONCACEN 2009. This study was funded by projects from the Agencia Nacional de Promoción Científica y Tecnológica (PICT 2010-2461) (granted to L. Venerus) and the Conservation, Research and Education Opportunities International (granted to the senior author). Field work was partially conducted within a World Natural Heritage Site and was authorized by the Secretaría de Turismo y Áreas Protegidas del Chubut.

\section{Literature cited}

Acha, E. M., M. Orduna, K. Rodrigues, M. I. Militelli, and M. Braverman.

2012. Caracterización de la zona de "El Rincón" (Provin- 
cia de Buenos Aires) como área de reproducción de peces costeros. Rev. Invest. Desarr. Pesq. 21:31-43.

Allen, L. G., and H. E. Block.

2012. Planktonic larval duration, settlement, and growth rates of the young-of-the-year of two sand basses (Paralabrax nebulifer and P. maculatofasciatus: fam. Serranidae) from Southern California. Bull. South. Calif. Acad. Sci. 111:15-21. Article

Amoroso, R. O., and D. A. Gagliardini.

2010. Inferring complex hydrographic processes using remote-sensed images: turbulent fluxes in the Patagonian gulfs and implication for scallop metapopulation dynamics. J. Coast. Res. 26:320-332. Article

Baldwin, C. C., and F. J. Neira.

1998. Serranidae (Anthiinae): sea basses, sea perches, wirrahs. In Larvae of temperate Australian fishes: laboratory guide for larval fish identification (F. J. Neira, A. G. Miskiewicz, and T. Trnski, eds.), p. 288-291. Univ. Western Australia Press, Nedlands, Australia.

Brownell, C. L.

1979. Stages in the early development of 40 marine fish species with pelagic eggs from the Cape of Good Hope. Ichthyol. Bull. J.L.B. Smith Inst. Ichthyol. 40, 84 p.

Ciechomski, J. D., and M. C. Cassia.

1976. Características de la reproducción y fecundidad del mero, Acanthistius brasilianus, en el Mar Argentino (Pisces; Serranidae). Physis 35:27-36.

Cousseau, M. B., and R. G. Perrotta.

2000. Peces marinos de Argentina: biología, distribución, pesca, $2^{\text {nd }}$ ed., 167 p. Instituto Nacional de Investigación y Desarrollo Pesquero, Mar del Plata, Buenos Aires, Argentina.

Cunha, M. E., P. Ré, H. Quental-Ferrerira, P. J. Gavaia, and

P. Pousao-Ferreira.

2013. Larval and juvenile development of dusky grouper Epinephelus marginatus reared in mesocosms. J. Fish Biol. 83:448-465. Article

Dell'Arciprete, O. P., H. E. Christiansen, and J. M. Díaz de Astarloa.

1987. Observaciones sobre el ciclo reproductivo del mero, Acanthistius brasilianus (Serranidae, Pisces). Rev. Invest. Desarr. Pesq. 7:67-84.

Galván, D. E., L. A. Venerus, and A. J. Irigoyen.

2009. The reef-fish fauna of the Northern Patagonian gulfs, Argentina, South-western Atlantic. Open Fish Sci. J. 2:90-98. Article

Harasti, D., C. Gallen, H. Malcolm, P. Tegart, and B. Hughes. 2014. Where are the little ones: distribution and abundance of the threatened serranid Epinephelus daemelii (Günther, 1876) in intertidal habitats in New South Wales, Australia. J. Appl. Ichthyol. 30:1007-1015. Article

Heemstra, P. C.

2010. Taxonomic review of the perciform fish genus Acanthistius from the east coast of southern Africa, with description of a new species and designation of a neotype for Serranus sebastoides Castelnau, 1861. Zootaxa 2352:59-68.

Irigoyen, A. J.

2006. Distribución espacial y temporal del mero (Acanthistius brasilianus) en la plataforma Argentina. B.Sc. thesis, 54 p. Universidad Nacional de la Patagonia San Juan Bosco, Puerto Madryn, Chubut, Argentina.
Irigoyen, A. J., L. Cavaleri Gerhardinger, and A. Carvalho-Filho. 2008. On the status of the species of Acanthistius (Gill, 1862) (Percoidei) in the South-West Atlantic Ocean. Zootaxa 1813:51-59.

Macpherson, E., and N. Raventos.

2006. Relationship between pelagic larval duration and geographic distribution of Mediterranean littoral fishes. Mar. Ecol. Prog. Ser. 327:257-265. Article

McClean, A. M.

1999. Patterns of settlement of juvenile kelp bass (Paralabrax clathratus) at Catalina Island during the summers of 1997 and 1998. M.Sc. thesis, 70 p. Calif. State Univ., Northridge, CA.

Nakamura, I., T. Inada, M. Takeda, and H. Hatanaka.

1986. Important fishes trawled off Patagonia, 369 p. Japan Marine Fishery Resource Research Center, Tokyo, Japan.

Neira, F. J., A. G. Miskiewicz, and T. Trnski.

1998. Methods. In Larvae of temperate Australian fishes: laboratory guide for larval fish identification (F. J. Neira, A. G. Miskiewicz, and T. Trnski, eds.), p. 11-19. Univ. Western Australia Press, Nedlands, Australia.

Nelson, J. S.

2006. Fishes of the world, $4^{\text {th }}$ ed., 601 p. John Wiley \& Sons Inc., Hoboken, NJ.

Potthoff, T.

1984. Clearing and staining techniques. In Ontogeny and systematics of fishes: based on an international symposium dedicated to the memory of Elbort Halvor Ahlstrom. Spec. Publ. 1 (G. Moser, W. J. Richards, D. M. Cohen, M. P. Fahay, A.W. Kendall, and S. L. Richardson, eds.), p. 35-37. Am. Soc. Ichthyologists and Herpetologists, Lawrence, KS.

Rubinich, J. P.

2001. Edad y crecimiento del mero Acanthistius brasilianus (Pisces, Serranidae) en el golfo San Matías, Argentina. B.Sc. thesis, 44 p. Universidad Nacional de la Patagonia San Juan Bosco, Puerto Madryn, Chubut, Argentina.

Sánchez, R. P.

1991. Current state of marine ichthyoplankton research in Argentina and Uruguay. Atlantica 13:215-231.

Sánchez, R. P., and M. Acha.

1988. Development and occurrence of embryos, larvae and juveniles of Sebastes oculatus with reference to two Southwest Atlantic Scorpaenids: Helicolenus dactylopterus lahillei and Pontinus rathbuni. Meeresforschungen 32:107-133.

Sánchez-Ramírez, M., and C. Flores-Coto.

1993. Desarrollo larvario y clave de identificación de algunas especies de la familia Carangidae del sur del Golfo de México. An. Inst. Cienc. Mar Limnol. Univ. Nac. Auton. Mex. 20:1-38.

Smith, W. L., and T. M. Craig.

2007. Casting the percomorph net widely: the importance of broad taxonomic sampling in the search for the placement of serranid and percid fishes. Copeia 2007:35-55. Article

Sparta, A.

1939. Contributo alla conoscenza dello sviluppo nei percidi. Uova, stadi embrionali e post-embrionali di Polyprion cernium. Consiglio Nazionale delle Ricerche. R. Comitato talassografico italiano. Memoria CCLIX. 
Taylor, W. R., and G. C. Van Dyke.

1985. Revised procedures for staining and clearing small fishes and other vertebrates for bone and cartilage study. Cybium 9:107-119.

Trnski, T., and T. M. Leis.

1991. A beginner's guide to illustrating fish larvae.

In Larval biology (D.A. Hancock, ed.), p. 198-202.
Australian Government Publishing Service. Bureau of Rural Resources Proceedings, Canberra, Australia.

Vigliola, L., and M. Harmelin-Vivien.

2001. Post-settlement ontogeny in three Mediterranean reef fishes of the genus Diplodus. Bull. Mar. Sci. 68:271-286. 